\title{
The Impacts of Multiple Intelligences on Tolerance of Ambiguity and English Proficiency-A Case Study of Taiwanese EFL College Students
}

\author{
Yi-An Hou \\ St. Mary's Junior College of Medicine, Nursing and Management, Taiwan \\ Email: hyn@smc.edu.tw
}

Received 7 April 2016; accepted 26 July 2016; published 29 July 2016

Copyright (C) 2016 by author and Scientific Research Publishing Inc. This work is licensed under the Creative Commons Attribution International License (CC BY). http://creativecommons.org/licenses/by/4.0/

\section{(c) (i) Open Access}

\begin{abstract}
The study was conducted to investigate how students' multiple intelligences were related to their tolerance of ambiguity and English proficiency. Subjects were 173 English major students in a private university in northern Taiwan, including 49 males and 124 females. They helped to fill out questionnaires of Multiple Intelligences (MI) (Gardner, 1983) and Second Language Tolerance of Ambiguity Scale (SLTAS) (Ely, 1995). In addition, students' English scores and English levels of Taiwan College Entrance Exam were used as their English proficiency. All available data received from the returned questionnaires were analyzed using descriptive and inferential statistics derived from SPSS 17. The results revealed that a correlation among students' multiple intelligences, tolerance of ambiguity, and their English proficiency did exist. In addition, by using t-test, findings showed that genders made a difference in students' multiple intelligences, tolerance of ambiguity, and English proficiency as well. Furthermore, implications derived from the study were provided for more effective English teaching and learning.
\end{abstract}

\section{Keywords}

Multiple Intelligences, Tolerance of Ambiguity, English Proficiency

\section{Introduction}

Introduction included 1) background of the study, 2) purpose of the study, and 3) research questions of the study. They were described below: 


\subsection{Background of the Study}

Any research investigating second/foreign learning can't avoid being dependent on the question: "Who learns what languages where" (Dornyei, 1994: p. 275). That is to say the learner, the target language, and the learning situation are the three major concerns of the study of second/foreign language. Especially, there has been an increasing interest in changing the focus from the language learning product to the language learning processes, together with the fact that the second half of the twentieth century can be called the age of individualism, when individual values and differences were recognized and respected (Shayeghi \& Hosseinioun, 2015: p. 2972), consequently the factors dealing with language learners have attracted much more attention than ever before. Such factors include "unchangeable" ones (such as age, gender, aptitude, and first language), and some other "predispositions" (motivation, attitude, tolerance of ambiguity, anxiety, field dependence/independence, cognitive styles, and learning strategies) (Jamieson, 1992). A great number of related studies have been conducted and have contributed to the field of second/foreign language a lot. However, not much research has been conducted to explore some "unchangeable" factors, together with some other "predispositions" at the same time. Hence, the present study attempted to focus on an "unchangeable" factor (gender), and some "predispositions", one affective style (tolerance of ambiguity) (TA) and one cognitive style (multiple intelligence, MI) (Gardner, 1983) to see how the theory of MI goes in a Taiwan setting where English is learned as a foreign language, in particular, how students with different genders and different intelligences present their tolerance of ambiguity (Ely, 1995) when learning a foreign language.

\subsection{Purpose of the Study}

The study aimed to investigate the impacts of multiple intelligences on tolerance of ambiguity and on college students' English learning. In addition, the study aimed to find out if genders made a difference in multiple intelligences, tolerance of ambiguity, and English learning.

\subsection{Research Questions}

The study was expected to provide answers to the two main research questions:

1) Is there any correlation among MI, AT and English proficiency?

2) Is there any difference on MI, AT and English proficiency between male students and female students?

\section{Related Literature}

The literature and related studies about Multiple Intelligences (MI) and Tolerance of Ambiguity (AT) were described as follows:

\subsection{Multiple Intelligences}

\subsubsection{On the Theory of Multiple Intelligences}

Intelligence is "the ability to solve problems or fashion products that are valued in one or more cultural settings", defined by Gardner (1993, p. 87). Gardner believed that we all have different combinations of intelligences which work together and make individuals different. But Gardner mentioned that our schools and culture focus most attention on linguistic and logical/mathematical intelligences and ignore other intelligences. He claimed that we should also place equal attention on those who show gifts in the other intelligences to enrich the world we live. So, Gardner created his theory of Multiple Intelligences (MI) in 1983. It is an important contribution to cognitive science and constitutes a learner-based philosophy which is an increasingly popular approach to characterizing the ways in which learners are unique and to developing instruction to respond to this uniqueness (Richards \& Rodgers, 2001: p. 123, sited in Arnold \& Fonseca, 2004: p. 119). It's known that Gardner had first listed the seven intelligences which met his criteria for intelligences, they were Linguistic/Verbal intelligence, Logical-Mathematical intelligence, Visual/Spatial intelligence, Musical/Rhythmic intelligence, Bodily-Kinesthetic intelligence, Interpersonal intelligence, and Intrapersonal intelligence. Later, he added the eighth intelligence (Naturalist intelligence), and worked for a possible ninth intelligence (Existential intelligence) (Gardner, 2003). It's been proved that MI theory is very important to educators because it helps us expand our horizon of available teaching/learning tools beyond the conventional linguistic and logical methods by nurturing intelligences in many different potential pathways for an individualized learning environment. Though the study of how MI 
theory has implemented around the world, in the $25^{\text {th }}$ anniversary of the publication of Frames of Mind: The Theory of Multiple Intelligences (2008), Gardner, the father of MI, wrote about "some various myths and misunderstanding of MI theory—for example, confusing an intelligence with a learning style...”

(http://www.old-pz.gse.harvard.edu/PIs/MIat25.pdf).

The Multiple Intelligence (MI) theory offers teachers a way to examine and adopt the best teaching techniques and strategies in light of student's individual differences. It also encourages educators to view learners as equals regardless of quotient produced from a traditional intelligence exam. Teachers are aware of the fact that every classroom is full of students with different areas of interest, different ways of expressing themselves, different strengths and weakness and recognize that an effective teaching and learning is to help students appreciate their strengths and improve their weakness. Without doubt that Gardner deserves everyone's gratitude, in particular, language teachers appreciate how well the theory is applied in the language-learning process. With the help of the theory, language teachers can create activities flexible, reflective, logical, and creative for diverse students' individual differences (Christison, 1998). Christison (1996) and McKenzie (2004) described clearly how Gardner conceived these intelligences (p. 11):

Logical/Mathematical Intelligence-the ability to use numbers effectively and reason well. Sample skills are understanding the basic properties of numbers, the principles of cause and effect, and the ability to predict.

Verbal/Linguistic Intelligence-the ability to use words effectively, both orally and in writing. Sample skills are remembering information, convincing others to help, and talking about language itself.

Visual/Spatial Intelligence-the ability to sense form, space, color, line, and shape. Sample skills include the ability to represent visual or spatial ideas graphically (items 21-30).

Bodily/Kinesthetic Intelligence-the ability to use the body to express ideas and feelings, and to solve problems. Sample skills are coordination, flexibility, speed, and balance.

Musical/Rhythmic Intelligence-the ability to sense rhythm, pitch, and melody. Sample skills are recognizing simple songs and being able to vary speed, tempo, and rhythm in simple melodies.

Interpersonal Intelligence-the ability to understand another person's moods, feelings, motivations, and intentions. Sample skills are responding effectively to other people, problem solving, and resolving conflict.

Intrapersonal Intelligence-the ability to understand yourself, your strengths, weakness, moods, desires, and intentions. Sample skills are understanding how one is similar to or different from others, reminding oneself to do something, knowing about oneself as a language learner, and knowing how to handle ones' feelings.

Naturalist Intelligence-the ability to recognize species of plants or animals in one's environment.

Existential Intelligence-the ability to see the "big picture": "Why are we here?" "What is my role in the world?”

\subsubsection{Related Recent Studies about Multiple Intelligences (MI)}

Some recent studies related to MI were described below:

In Korea, to investigate the relevance of Multiple Intelligence (MI) to the instruction of Computer-Assisted Language Learning (CALL), Kim (2009) conducted an experimental study in Korea. Subjects were 39 university junior and senior English and Literature majors, who were enrolled in a 16-week multimedia technology language course. The research instruments used in the pre-test and post-test were the 50-item listening test of Test of English for International Communication (TOEIC) and the 80-item Korean MI questionnaire. According to Kim (2009), the Korean MI questionnaire was “...modified from existing MI inventories (Christison, 1998; and Armstrong, 2000)”, but also “...included an eight, Natural intelligence, proposed in Gardner’s (1999) later work', though these results were negligible and not included in this study” (Kim, 2009: p. 7). Unlike other MI inventories which normally included seven sections with 10 items all dealing with the same kind of intelligence, the Korean MI questionnaire consisted of ten sections with 8 items, and each item was dealing with one type of the eight intelligences. During the 16-week course teaching process, Kim analyzed the contents of materials from his CALL instruction for each class perios and calculated the amount of time spent on CALL instruction linked to each type of intelligence. Among them, Verbal/Linguistic intelligence was spent $40 \%$ of each class period, followed by Visual/Spatial intelligence and Intrapersonal intelligence, 20\%, then Logical/Mathematical intelligence and Interpersonal intelligence (10\%). As for Bodily/Kinesthetic intelligence and Musical intelligence, there was no class time spent on them because they were excluded in in the course syllabus (Kim, 2009: p. 8). Findings revealed that "CALL instruction helped students improve their TOEIC listening scores as well as their MI quotients in significant ways" (Kim, 2009: p. 13), and it was concluded that "CALL software can be effec- 
tively used to enhance the many kinds of human intelligences employed when learning languages” (Kim, 2019: p. 1).

In Taiwan, Hou \& Cheng (2014) conducted a study to investigate the nine intelligences and six perceptual learning style preferences in college students' academic performance. A total of 187 Taiwanese college freshman students from six departments served as subjects of the study, including 96 males and 101 females. In addition to their scores of Taiwan College Entrance Exam adopted as their academic performance, the research instruments included two surveys of the Nine Intelligences (MI) (Gardner, 1983, 2000; Christison, 1998) and the six perceptual Learning Style Preference (PLSP) (Reid, 1998). Findings revealed that Taiwanese college students were stronger with Existential intelligence (1), followed by Musical intelligence (2), Visual/Spatial intelligence (3), Intrapersonal intelligence (4) and Interpersonal intelligence (5). On the other hand, they were weaker with Universal intelligence (9), followed by Logical/Mathematic intelligence (8), Bodily intelligence (7), and Verbal/Linguistic intelligence (6). Additionally, male students were found to have higher mean in total multiple intelligences $(p<.01)$, particularly in Logical/Mathematic intelligence $(p<.01)$, Visual/Spatial intelligence $(p<.05)$, Bodily intelligence $(p<.01)$, Universal/Naturalist intelligence, $(p<.05)$, and Existential intelligence $(p<.05)$. Furthermore, MI was found to be related to students' learning styles and academic performance as well. For example, students with stronger Bodily intelligence tended to prefer kinesthetic styles, tactile styles, and group styles. Additionally, regarding to college entrance exam scores, students' Logical/Mathematic intelligence was found to be a positive predictor of their math scores while their Verbal/Linguistic intelligence was found to be a negative predictor of their math scores, and Musical intelligence was a positive predictor of both Chinese scores and English scores.

Another study conducted in Taiwan by Hou, Hou, \& Cheng (2015) investigated some possible factors related to Taiwanese college students' English performance. Subjects were 50 college English major students, including 11 males and 39 females. Their TOEIC scores of listening and reading were adopted as their English performance. In addition, the research instrument was a set of questionnaire dealing with students' English learning behavior, including motivation and attitude (Gardner, 1983), beliefs (Horwitz, 1988), anxiety (Horwitz, Horwitz, \& Cope, 1986), strategy (Oxford, 1995), and styles (Reid, 1995) as well as multiple intelligences (Gardner, 1983, 2000). Findings showed that factors related to students' TOEIC listening scores were anxiety (negatively) and motivation, while factors related to TOEIC reading scores were attitude and kinesthetic learning styles. In the study, beliefs, strategy use, and multiple intelligences were not found to be related to TOEIE scores of listening and reading.

In Canada. Visser, Ashton, \& Vernoon (2006) investigated Gardner's “Theory of Multiple Intelligences” by selecting two tests based on Gardner's description of its content. Subjects were a sample of 200 university adults, including 84 males and 116 females. Among them, 171 were current undergraduate students, and the remainders were current graduate students, non-academic employees of the university, and non-students friends or relatives of the undergraduate student participants, ranging from 17 to 66 years old. By factor analysis, findings revealed that "a large g factor having substantial loading for tests assessing purely cognitive abilities-Linguistic, Logical/Mathematical, Spatial, Naturalistic, Interpersonal-but lower loadings for tests of other abilities, especially Bodily-Kinesthetic". Their results support previous findings "that highly diverse tests of purely cognitive abilities share strong loadings on a factor of general intelligence, and that abilities involving sensory, motor, or personality influences are less strongly g-loaded". The authors claimed that "Gardner is likely correct in claiming that Bodily-Kinesthetic ability is quite different from the various cognitive abilities" and suggested that "given the important contribution of non-cognitive as well as cognitive abilities to performance in the Bodily-Kinesthetic, Musical, and Intrapersonal domains, 'talents' might be a more appropriate label than 'intelligences’”.

In Iran, Akbari \& Hosseini (2008) investigated the existence of possible relationship between the use of language learning strategies, multiple intelligences, and English scores of foreign language learners of English. Subjects were 90 university English majors in Iran, including 37 males and 53 females. In addition to subjects' reading scores of International English Language Testing System (IELTS) were used as their English proficiency, the research instruments were a Persian version of the Strategy Inventory for Language Learners (SILL) (Oxford, 1995), and Multiple Intelligences Developmental Assessment Scales (MIDAS) (Shearer, 1996). The findings indicated that "there are relatively low, but positive, significant correlations among different strategy types and overall MI scores” (p. 151). However, among the individual intelligences, musical intelligence was found not significantly correlate with any strategy use type, and linguistic intelligence didn't correlate with social strategy, either. As for the relation between MI and English proficiency, it was found that among the eight 
intelligences, only the Verbal/Linguistic intelligence was a predictor of English proficiency $(p<.05)$.

In Mexico, Carlin, Salazar, \& Cortes (2013) conducted a study in a Mexican English teacher education program about multiple intelligences. Subjects were 74 first year students, including19 males and 55 females. Findings reveal that the highest kinds of intelligences were Bodily/Kinesthetic, Interpersonal, Intrapersonal, and Musical; while the lowest ones were Naturalist, Existential, Verbal/Linguistic, Logical/Mathematic and Visu$\mathrm{al} /$ Spatial, and it is suggested "to diagnose and promote these intelligences in trainees in a systematic way to equip them with knowledge and experience of multiple intelligences”.

In 2014, Saeidi \& Karvandi (2014) investigate the existence of any possible relationship between Iranian intermediate English as a foreign language (EFL) learners' multiple intelligence (MI) and their performance on reason-gap type of writing task. The subjects were 40 Iranian EFL learners, including 17 males and 23 females. The two research instruments were Multiple Intelligence Development Assessment Scales (MIDAS) (Shearer, 1996), and a reason-gap writing task. In the study, the Iranian EFL learners are stronger with Interpersonal intelligence (1) and Intrapersonal intelligences (2), followed by Linguistic/Verbal intelligence (3) and Logical/Mathematic (4), but they are weaker with Musical intelligence (8), followed by Kinesthetic intelligence (7), Natural intelligence (6) and Visual/Spatial intelligence (5), The results also indicate that there is a statistically significant and positive relationship between the participants' performance on reasoning-gap writing task and Logical/Mathematical, Interpersonal and Intrapersonal intelligences.

In Spain, del Mar Palenzuela Perez \& Ruz (2014) proposed a program based in the Intrapersonal intelligence in order to increase the students motivation. Subjects were fifteen L2 learners who want to reach B1 on the Common European Framework. The starting level is an advanced A2, and most of them are between 19 and 22. The authors designed tasks to develop intrapersonal intelligence in order to enhance student motivation while the students acquire the language course content. The program was divided into five sessions from Monday to Friday, for four hours a day. The L2 language tasks were implemented to focus on listening and speaking skills as intrapersonal intelligence. The results showed that the methodology which develops the intrapersonal intelligence helps the students to know themselves and hence apply this knowledge to develop learning strategies based on their strong points.

\subsection{Tolerance of Ambiguity}

\subsubsection{On the Theory of Tolerance of Ambiguity}

Tolerance of ambiguity is a person's ability to function properly in a situation where the interpretation of the stimuli is unclear. Budner (1962) defined it as "the tendency to perceive ambiguous situations as desirable" (p. 29). In addition, Ehrman $(1994,1999)$ pointed out that there were three levels of function for tolerance of ambiguity, including intake, tolerance of ambiguity proper, and accommodation. During the three levels, when facing ambiguity or uncertainty situation, learners would be letting it in, accepting contradictions and incomplete information, and making distinctions, setting priorities, and restructuring cognitive schemata. As for intolerance of ambiguity, it was defined as "the tendency to perceive (i.e. interpret) ambiguous situations as sources of threat" (Budner, 1962: p. 29), or "a tendency to perceive or interpret information marked by vague, incomplete ... or unclear meanings as actual or potential sources of psychological discomfort or threat” (Norton, 1975: p. 608). Hence, tolerance of ambiguity can be seen as a person's characteristics to functionally perceive information in ambiguous situations or to become sources of psychological discomfort or threat. People with little tolerance of ambiguity are believed to experience more discomfort (Ely, 1995) and anxiety (Chapelle, 1983); to make guess early or agree with popular misconceptions (Levitt, 1953). They prefer memory or strategies which involve focusing on individual language elements (Ely, 1989), are more rigid (MacDonald, 1970) and less inclined to take risks (Ely, 1995). They are easy to resort to black-and-white solutions (Frenkel-Brunswik, 1949), have the tendencies to avoid ambiguous situations (Chapelle \& Roberts, 1986), or even drop the subject (Naiman et al., 1975). On the contrary, people with more tolerance of ambiguity appreciate being in ambiguous situations. They are willing to take risks, and are more receptive to change (McLain, 1993). By using more facility strategies, they can function better, gain more and excel in performance. It seems that people with more tolerance of ambiguity tend to have the advantage to become good language learners, while those with little or no tolerance of ambiguity have the disadvantage to suffer from psychological discomfort and linguistic uncertainty.

\subsubsection{Related Studies about Tolerance of Ambiguity}

There are some studies dealing with learners' tolerance of ambiguity. First, O’Connor (1952) used Walk’s A 
Scale to investigate the relationship between tolerance of ambiguity and ethonocentrism. Subjects were 77 undergraduate students. Findings showed that performance on Walk's A Scale positively associated with ethonocentrism. But in Pimsleuv, et al.'s (1966), in which the same instrument was used to relate tolerance of ambiguity to second language success, no relationship between the two factors was found. Levitt (1953) conducted the Misconception Scale (the M-Scale) to investigate the usefulness of it and Etzel's (1953) Decision-Location Test (DLT), as well as to determine their relationship to ethnocentrism in children at the grade school level. Subjects were 47 elementary school students, and the findings indicated that both the perceptual measure (DLT) and the cognitive measure (the M-Scale) are significantly related, and intolerance of ambiguity and ethnocentrism are associated characteristics in elementary school children. Then, Budner (1962) developed a very widely used 16-item scale for ambiguity tolerance. A total of 17 samples, including 946 college students in New York City served as the subjects. Findings included that the ambiguity scale was correlated with conventionality and authoritarianism. But the reliabilities were not satisfactory, indeed it was "with the mean of the scale in these samples being approximately 49”. (Budner, 1962: p. 34). Ehrlich (1965) used 216 university students to test the reliability of Walk's A Scale. It was claimed that though "performance on Walk's A Scale is related to performance on the component measures of authoritarianism" (p.593), yet the scale has "virtually no internal consistency" (p.591). So, the author suggested that Walk's A Scale should not be considered as a pure measure of intolerance of ambiguity. MacDonald (1970) found that ambiguity tolerance is related to performance of ambiguous tasks. People with more tolerance tend to excel in ambiguous tasks. After that, Naiman et al. (1975) used Budner's scale to investigate good language learners' characteristics. Subjects were high school students who were learning French as a second language. It was found that AT is positively related to imitation tasks and listening tasks for grade 8 students. In addition, 10 and 12 graders were more tolerant of ambiguity than 8 graders. Chapelle (1983) used Norton's (1975) MAT-50 as one of the measuring instruments to investigate the relationship between AT and English success. Subjects were 61 international university students who were learning English as a foreign language, including 20 Arabic speakers, 13 Japanese speakers, and 28 Spanish speakers. Findings included that AT is a significant predictor of end-of-semester grammar task, dictation task, and total English placement test. As a whole, AT was found to be negatively related to success in acquiring that target language. Furthermore, Japanese speakers were found to be more tolerant of ambiguity than other speakers of Arabic and Spanish. Later, in Chapelle's other studies, it was pointed out that AT is related to Field Dependence/Independence (Chapelle \& Roberts, 1986), and is a predictor of TOEFL scores (Test of English as a Foreign Language) (Chapelle \& Roberts, 1986). Furthermore, Ely (1986) conducted scales of second language classroom discomfort, risk taking, sociability, and motivation to investigate 84 university students learning Spanish as a foreign language. Findings showed that risk-taking and classroom discomfort (something to do with AT) are related to participation which leads to language proficiency. Later, to represent various aspects of language learning and use, Ely (1989) conducted the 12-item second language AT Scale (Spanish) to determine whether AT influences learners' language strategy use, and the answer was positive. AT was found "to be a significant negative predictor of various strategies which involve focusing on individual language elements...” (Ely, 1989: p. 442). Like Pimsleur, et al.'s (1966) study, Chen's (1989) found no relationship between AT and English proficiency. In her study, Norton's (1975) MAT-50 is one of the instruments, and subjects are 48 cadets at the Chinese Military Academy who are learning English as a foreign language. The most influential indicator of subjects' overall English achievement was found to be language aptitude. McLain (1993) constructed a 22-item Multiple Stimulus Types Ambiguity Tolerance (MSTAT). Subjects are 148 undergraduate students. Findings show that AT is positively related to willingness to take risks, cognitive complexity, and receptivity to change. Later, what with Ely's Second Language Tolerance of Ambiguity Scale (English version) (1995) and what with English has become the "Lingua Franca", the communicating language, studies of the effects of tolerance of ambiguity, together with other factors related to ESL/EFL learning, have become more and more popular themes worldwide in EF learning situations than ever before, such as China (Wen, 2003; Xu, 2005; Du, 2006; Liu, 2006; Bu, 2007; Li, 2007; Yu, 2007; Lai, 2009; Wu, 2009; Li, 2010; Liu; 2011; Liu, 2015), Korea (Lee, 1998), Japan (Fukuchi \& Sakamoto, 2005; Kondo-Brown, 2006); Iran (Khajeh, 2002; Rostami, 2010; Kamran, 2011; Marzban et al. 2012; Zarashan \& Ardeshiri, 2012), Egypt, (El-Koumy, 2000), Turkey (Erten \& Topkays, 2009), Greek (Karamia, 1999), and many others. In short, some studies of ambiguity tolerance deal with the relationship between AT and ethnocentrism or authoritarianism (O’Conner, 1952; Levitt, 1953; Budner, 1962; Ehrlich, 1965; Chapelle, 1983); some refer to AT and learners' rigidity or receptivity of change (MacDonald, 1970; McLain, 1993); some mention about AT and other variables, such as Field Dependence/Independence (Chapelle \& Roberts, 1986), or 
strategy use (Ely, 1989); some focuse on AT and second/foreign language success (Pimsleur et al., 1966; Naiman, 1975; MacDonald, 1970; Chapelle, 1983; Chapelle \& Roberts, 1986; Chapelle \& Roberts, 1986; Ely, 1986, 1989; Chen, 1989). Subjects of many studies are university students, with an exception in Levitt's (1953), in which subjects are elementary school students, and in Naiman et al.'s (1975), in which subjects are high school students. The most frequently used instruments for measuring AT are Budner's (1962) and Norton's (1975). Findings are various and inconsistent. Nevertheless, except in Pimsleur, et al.'s (1966) and in Chen's (1989), in which AT is found unrelated to language success, many studies have explored that AT is related to the investigating variable(s) in one way or another. In particular, the relationship between AT and second/foreign has become one of the major concerns in the study of ambiguity tolerance. Especially after Elys' English version of Second Language Tolerance of Ambiguity Scale was developed in 1995, and English has been the "Lingua Franca", studies about the effects of tolerance of ambiguity, together with other factors related to ESL/EFL learning, have become more and more blooming worldwide in EF learning situation than ever before.

\section{Methodology}

Methodology included 1) research design, 2) subjects of the study, 3) research instruments, and 4) procedure. They were described below:

\subsection{Research Design}

A case study was used for the research methodology because the focus of attention is the case, not the whole population of cases. In addition, a case study has the advantages of combining qualitative and quantitative data in a complementary way (Stake, 1988), and in providing a depth study of a special case as well. "Some case studies are highly impersonal and statistical” (Stake, 1988: p. 256). It is the study of a bounded system, which is in a particular circumstance and with a particular problem, and also gives readers "space" for their own opinions.

\subsection{Subjects of the Study}

Subjects were 178 English major students in a private university in Northern Taiwan, including 50 males and 128 females. They were about 31\% of the whole population of the Department. Among them, 75 were freshmen, 41, sophomores, 33, juniors, and 29, seniors. Subjects of the study were presented in Table 1.

\subsection{Research Instruments}

The research instruments of the study included two questionnaires of Multiple Intelligences (Gardner, 1983) and Ely's Second Language Tolerance of Ambiguity Scale (SLTAS) (1995). The former is the most popular survey dealing with Multiple Intelligences (MI), which is in Likert-scale format with a five responses of Strongly Agree $(\mathrm{SA}=5)$, Agree $(\mathrm{A}=4)$, No Comment $(\mathrm{NC}=3)$, Disagree $(\mathrm{D}=2)$, and Strongly Disagree $(\mathrm{SD}=1)$; while the latter, it was the only scale of tolerance of ambiguity designed specifically for foreign/second language learning context. Particularly, the items represent a broad spectrum of language activities of listening, speaking, reading comprehension, writing, lexical development, pronunciation, and grammar learning (Ely, 1995), which really represent the types of language learning that the students are experiencing. Regarding counting each of the scores of SLTAS, unlike MI. the responses are in Likert-scale format with a set of four responses: Strongly Agree $(S A=4)$, Agree $(A=3)$, Disagree $(D=2)$, and Strongly Disagree $(S D=1)$ (Ely, 1995). Students were leveled as Low SLTA, Moderate SLTA, and High SLTA. In the study, the higher the points, the lower the tolerance of

Table 1. Subjects of the study.

\begin{tabular}{|c|c|c|c|c|c|c|}
\hline & & \multicolumn{4}{|c|}{ Grade } & \multirow{2}{*}{ Total } \\
\hline & & Freshman & Sophomore & Junior & Senior & \\
\hline \multirow{2}{*}{ Gender } & Male & 20 & 14 & 7 & 9 & 50 \\
\hline & Female & 55 & 27 & 26 & 20 & 128 \\
\hline \multicolumn{2}{|c|}{ Total } & 75 & 41 & 33 & 29 & 178 \\
\hline
\end{tabular}


ambiguity, and points between 1.0 - 2.0, 2.1 - 3.0, and 3.1 - 4.0 were regarded as High SLTA, Moderate SLTA, and Low SLTA, respectively.

In addition, to understand the participants' English level to make sure that the scale was grammatically and lexically appropriate for them, students' English test results were used as their English proficiency, namely, English levels of their College Entrance Exam (CEE) (2015) or/and their English scores of their College Entrance Advanced Subjects Test (CEAST) (2015). The full score of the two tests is 100 points, and in CEAST, English scores were divided into 15 levels with a range of 6.32 points, for example, Level 15 was ranging from 88.49 to100, while Level 14 was ranging from 82.17 to 88.48, etc. Both of the English tests included two parts, one was reading (56 items, 72 points), and the other was writing (2 translations and 1 writing, 28 points). In Taiwan, to get into colleges, high school seniors (or graduates) can take CEE or/and CEAST held in late January, and early July, respectively; the higher the levels/scores, the better college students are granted admission. After realizing the participants' English proficiency was not quite satisfactory (in fact, the mean score of the whole participants was 33.84 points out of 100 points, or level 7.95 out of 15), partly with the intention of avoiding some students' possible misunderstanding of the item contents for language proficiency limitation, and partly "if we have a group of students who all speak the same first language, we can use a translated form of an instrument-noting” (Liu, 2015: p. 1875), a bi-lingual English-Chinese version of Multiple Intelligences and SLTAS was adopted in the present study. The details of the instruments of the study were displayed in Table 2.

\subsection{Procedure}

The study was conducted to investigate college students' tolerance of ambiguity and the effects on their English learning. To avoid possible unnecessary misunderstanding, items of Second Language Tolerance of Ambiguity Scale (SLTAS) (Ely, 1995) were displayed in both English and Chinese by the researcher. Three weeks prior to the study, a pilot study was carried out by 28 freshmen, and the Cronbach's alpha internal consistency reliability was found to be .875 . Then, in the late 2015, a total of 282 English major students in the university were arranged to fill out the two questionnaires of multiple intelligences and Tolerance of Ambiguity (including the 28 pilot-study-takers). If they agreed to participate in the study, they would sign their names on the answer sheet, if not, they didn't need to do that. Hence, discarding name-blank and incomplete ones, 178 answer sheets (63\%) were remained which were investigated in data analysis phrase. In other words, about $37 \%$ of the participants were excluded from the data analysis when investigating factors relating to students' English scores/levels. In the study, students' English scores of College Entrance Exam (CEE) (2015) and/or English Levels of College Entrance Advanced Subject Test (CEAST) (2015) on files were used as their English proficiency. The mean score of the English levels of the subjects in the study was 7.95 (equivalent scores were about 44.25 - 50.56), while normally the passing level were about 10, and the equivalent scores were between 56.89 - 63.20. The subjects' English levels were presented in Table 3.

Table 2. Instruments of the study.

\begin{tabular}{|c|c|c|c|c|c|c|c|}
\hline Questionnaire I & Subcategories & Item & Number & Questionnaire II & Subcategories & Item & Number \\
\hline \multirow{9}{*}{$\begin{array}{l}\text { Multiple intelligence } \\
\text { (MI) (Gardner, 1983) }\end{array}$} & $\begin{array}{c}\text { Logical/ } \\
\text { Mathematical }\end{array}$ & 10 & $01-10$ & \multirow{7}{*}{$\begin{array}{l}\text { Second Language Tolerance } \\
\text { of Ambiguity Scale } \\
\text { (SLTAS) Ely, } 1995\end{array}$} & Listening & 1 & 2 \\
\hline & $\begin{array}{c}\text { Verbal/ } \\
\text { Linguistic }\end{array}$ & 10 & $11-20$ & & Speaking & 1 & 10 \\
\hline & Visual/Spatial & 10 & $21-30$ & & Reading & 3 & $1,6,12$ \\
\hline & Bodily & 10 & $31-40$ & & Writing & 2 & 3,8 \\
\hline & Musical & 10 & $41-50$ & & Lexical development & 2 & 9,11 \\
\hline & Interpersonal & 10 & $51-60$ & & Pronunciation & 1 & 5 \\
\hline & Intrapersonal & 10 & $61-70$ & & Grammar & 2 & 4,7 \\
\hline & $\begin{array}{l}\text { Universal/ } \\
\text { Naturalist }\end{array}$ & 10 & $71-80$ & English scores, $\mathrm{CEE}^{1}$ & Reading + writing & $56+3$ & \\
\hline & Existential & 10 & $81-90$ & English levels, CEAST $^{2}$ & Reading + writing & $56+3$ & \\
\hline
\end{tabular}

${ }^{1}$ College Entrance Exam, Taiwan. Scores: $72+28=100$ points. ${ }^{2}$ College Entrance Advanced Subjects Test, Taiwan. Scores: $72+28=100$ points and 1 - 15 levels. 
Table 3. Subjects’ English levels of college entrance advanced subject test.

\begin{tabular}{|c|c|c|c|c|}
\hline \multicolumn{2}{|r|}{ English levels } & \multirow{2}{*}{$\begin{array}{c}\text { Number } \\
0\end{array}$} & \multirow{2}{*}{$\begin{array}{l}\% \\
0\end{array}$} & \multirow{2}{*}{$\begin{array}{c}\text { English scores } \\
0.00-0.00\end{array}$} \\
\hline & 0.00 & & & \\
\hline & 1.00 & 0 & 0 & $0.01-6.32$ \\
\hline & 2.00 & 0 & 0 & $6.33-12.64$ \\
\hline & 3.00 & 4 & 2.6 & 12.65 - 18.96 \\
\hline & 4.00 & 7 & 4.5 & $18.97-25.28$ \\
\hline & 5.00 & 9 & 5.8 & 25.29 - 31.60 \\
\hline & 6.00 & 30 & 19.4 & 31.61 - 37.92 \\
\hline \multirow{9}{*}{ Level } & 7.00 & 37 & 23.9 & $37.93-44.24$ \\
\hline & 8.00 & 29 & 18.7 & $44.25-50.56$ \\
\hline & 9.00 & 17 & 11.0 & $50.57-56.88$ \\
\hline & 10.00 & 13 & 8.4 & $56.89-63.20$ \\
\hline & 11.00 & 6 & 3.9 & $63.21-69.52$ \\
\hline & 12.00 & 1 & .6 & $69.53-75.84$ \\
\hline & 13.00 & 2 & 1.3 & 75.85 - 82.16 \\
\hline & 14.00 & 0 & 0 & $82.17-88.48$ \\
\hline & 15.00 & 0 & 0 & $88.49-100.00$ \\
\hline Mean & Total 7.95 & 155 & 100.0 & 100.0 \\
\hline
\end{tabular}

'In the study, the higher the levels, the better the students' English proficiency.

Along with descriptive statistics of mean and standard deviation, the data was analyzed by using The Statistical Package for the Social Science (SPSS) to perform three analyses. First, Pearson product-moment correlation was computed to find out the relationship between students' English scores and English levels of the College Entrance Exam. Then, a Regression Analysis was used to determine 1) if multiple intelligences were predictive to tolerance of ambiguity and English scores or English levels, and 2) If tolerance of ambiguity was predictive to English scores or English levels, and 3) if the correlation existed among multiple intelligences, tolerance of ambiguity, and English scores or English levels. In addition, a t-Test was calculated to investigate whether there were significant differences on multiple intelligences, tolerance of ambiguity, and English scores or English levels between males and females.

\section{Findings and Results}

Findings of the study included 1) reliability of the research instrument, 2) descriptive analysis of students' MI, AT, and English levels, 3) relationship between English scores and English levels, 4) analysis of multiple intelligences, 5) analysis of tolerance of ambiguity, 6) gender differences of multiple intelligences, tolerance of ambiguity, and English scores/levels, 7) regression analysis of multiple intelligences, tolerance of ambiguity, and gender, predicting English levels, and 8) correlation among subcategories of multiple intelligences, tolerance of ambiguity, and English levels. They were described below:

\subsection{Reliability of Multiple Intelligences and Second Language Tolerance of Ambiguity Scale}

The reliability of Multiple Intelligences (Gardner, 1983) and The Second Language Tolerance of Ambiguity Scale (SLTMS) was Cronbach's Alpha .960 ( $\mathrm{N}$ of Cases $=90$ ) and .873 ( $\mathrm{N}$ of Cases $=12$ ), respectively. "If a test were perfectly reliable, the reliability coefficient would be 100 . However, no test is perfect reliable”. (Gay \& 
Airasian, 2003: p. 141). Hence, the results of the Cronbach’s Alpha internal consistency reliability .960 and .873 indicated that the research instruments of the study were quite reliable. The finding was presented in Table 4.

\subsection{Descriptive Analysis of Students' MI, AT, English Scores and English Levels}

The mean score of students' English scores was 33.84 points out of 100 points (ranging from 12.5 to 65.50 points), and the full scores of the test was 100 points. As for the English levels, the mean score was 7.95, out of 15, ranging from level 3 (ranging 12.65 - 18.96 points) to level 13 (75.85 - 82.16 points), and the highest level was 15. Referring to students' tolerance of ambiguity, the mean score was 2.70 out of 4.00 , which was regarded as moderate level, inclining to low level of tolerance of ambiguity. As for multiple intelligences, the mean score was 3.25 out of 5.00. The descriptive analysis of students' English scores, levels and tolerance of ambiguity was presented in Table 5.

\subsection{Analysis of Multiple Intelligences}

The following analysis included descriptive analysis of mean and standard deviation of multiple intelligences, correlation among subcategories of multiples intelligences, and regression analysis of multiple intelligences predicting tolerance of ambiguity and English scores and levels. They were described below:

\subsubsection{Mean and Standard Deviation of Multiple Intelligences}

The findings revealed that students were stronger with those intelligences as Existential Intelligence $\left(1^{\text {st }}\right)$, Musi$\mathrm{cal} /$ Rhythmic Intelligence $\left(2^{\text {nd }}\right)$, Intrapersonal Intelligence $(3 r d)$, and Visual/Spatial Intelligence $\left(4^{\text {th }}\right)$, and Ver$\mathrm{bal} /$ Linguistic Intelligence $\left(5^{\text {th }}\right)$. On the other hand, they were weaker with Interpersonal Intelligences $\left(6^{\text {th }}\right)$. Bodily Intelligence $\left(7^{\text {th }}\right)$, Logical/Mathematical Intelligence $\left(8^{\text {th }}\right)$, and Universal/Naturalist Intelligence $\left(9^{\text {th }}\right)$. The findings were displayed in Table 6.

\subsubsection{Correlation Among Subcategories of Multiple Intelligences}

The findings revealed that all the subcategories of multiple intelligences were strongly correlated to one another, except for logical intelligence to musical intelligence and interpersonal intelligence. The findings were presented in Table 7.

\subsubsection{Regression Analysis of Multiple Intelligences Predicting Tolerance of Ambiguity and English Scores and Levels}

Among the subcategories of multiple intelligences, it was found that variables predictive to tolerance of ambiguity were logical/mathematic intelligence $(p<.01)$, verbal/linguistic intelligence negatively $(p<.05)$, and visual/spatial intelligence $(p<.05)$. The findings were presented in Table 8.

Table 4. Reliability of the research instruments.

$\begin{array}{ccc}\text { Questionnaire } & \text { Cronbach’s Alpha } & \text { N of items } \\ \text { Multiple intelligences (MI) } & .960 & 90 \\ \text { Second Language Tolerance of Ambiguity Scale (SLTAS) } & .873 & 12\end{array}$

Table 5. Descriptive analysis of students' english levels, AT and MI.

\begin{tabular}{|c|c|c|c|c|c|}
\hline & $\mathrm{N}$ & Min & Max & M & SD \\
\hline English scores & 65 & 12.50 & 65.50 & 33.8462 & 11.40173 \\
\hline English levels & 135 & 3.00 & 13.00 & 7.9556 & 1.95038 \\
\hline Tolerance of ambiguity & 178 & 1.00 & 4.00 & 2.7088 & .51904 \\
\hline Multiple intelligences & 152 & 1.00 & 4.34 & 3.25 & .49516 \\
\hline Missing $^{*}$ & 35 & & & & \\
\hline
\end{tabular}

"Missing indicated that those questionnaire answer sheets were with no names or insufficient information. 
Table 6. Mean and standard deviation of Multiple Intelligences.

\begin{tabular}{cccccccc}
\hline & $\mathrm{N}$ & $\mathrm{Min}$ & $\mathrm{Max}$ & $\mathrm{M}$ & $\mathrm{SD}$ & rank \\
\hline Logical/mathematical intelligence & 178 & 1.00 & 4.80 & 2.8118 & .73763 & $(8)$ \\
Verbal/linguistic intelligence & 178 & 1.00 & 4.90 & 3.2022 & .69257 & $(5)$ \\
Visual/spatial intelligence & 178 & 1.00 & 5.00 & 3.4140 & .71266 & $(4)$ \\
Bodily intelligence & 178 & 1.00 & 5.00 & 3.0551 & .74311 & $(7)$ \\
Musical/rhythmic intelligence & 178 & 1.00 & 5.00 & 3.5365 & .85837 & $(2)$ \\
Interpersonal intelligence & 178 & 1.00 & 5.00 & 3.1809 & .72624 & $(6)$ \\
Intrapersonal intelligence & 176 & 1.00 & 5.00 & 3.4563 & .64131 & $(3)$ \\
Universal/naturalist intelligence & 178 & 1.00 & 5.00 & 2.7949 & .73487 & $(9)$ \\
Existential intelligence & 154 & 1.00 & 5.00 & 3.7416 & .75846 & $(1)$ \\
All MI & 152 & 1.00 & 4.34 & 3.2531 & .49516 & \\
\hline
\end{tabular}

\subsection{Analysis of Second Language Tolerance of Ambiguity Scale (SLTAS)}

The following analysis included descriptive analysis of mean and standard deviation of tolerance of ambiguity, correlation among subcategories of tolerance of ambiguity, and regression analysis of tolerance of ambiguity predicting English scores and levels. They were described below:

\subsubsection{Subcategories of Second Language Tolerance of Ambiguity Scale (SLTAS)}

Based on the content of each item of Second Language Tolerance of Ambiguity Scale (SLTAS), all of the 12 items were divided into 7 language components as listening (item 2), speaking (item 10), reading (items 1, 6, 12), writing (items 3, 8), lexical development (items 9, 11), pronunciation (item 5), and grammar.(items 4, 7). The findings revealed that students were lower tolerant of ambiguity in Writing, Grammar, Pronunciation, and listening, followed by Speaking, lexical development, and Reading. The findings were displayed in Table 9.

\subsubsection{Correlation among Subcategories of Tolerance of Ambiguity}

The findings showed that all the seven language skills were strongly correlated to one another $(p<.01)$, which were presented in Table 10.

\subsubsection{Regression Analysis of Tolerance of Ambiguity Predicting English Scores and Levels}

The findings showed that among the subcategories of tolerance of ambiguity, only tolerance of ambiguity of reading was negatively predictive English scores $(p<.01)$. The findings were displayed in Table 11.

\subsection{Gender Differences of Multiple Intelligences, Tolerance of Ambiguity, English Scores and Levels}

The analysis included gender differences of multiple intelligences, tolerance of ambiguity, English scores and levels. They were described below:

\subsubsection{Gender Differences of Multiple Intelligences}

Findings showed that males had higher means in bodily intelligence $(p<.05)$ and universal/naturalist intelligence $(p<.01)$ than females, which was shown in Table 12 .

\subsubsection{Gender Differences of Tolerance of Ambiguity}

It was found that females had higher mean in tolerance of ambiguity of listening than males $(p<.01)$, which was shown in Table 13.

\subsubsection{Gender Differences of English Scores and Levels}

As for the differences on English scores and levels, though males seemed to have higher means in both English scores and levels than females, yet none reached the significant levels. The findings were presented in Table 14. 
Table 7. Correlation among subcategories of multiple intelligences.

\begin{tabular}{|c|c|c|c|c|c|c|c|c|c|c|}
\hline & & Logical & Verbal & Spatial & Bodily & Musical & Interpersonal & Intrapersonal & Universal & Existential \\
\hline \multirow[t]{3}{*}{ Logical } & $\begin{array}{l}\text { Pearson } \\
\text { correlation }\end{array}$ & 1 & $.363\left(^{* *}\right)$ & $.460\left(^{* *}\right)$ & $.309\left(^{* *}\right)$ & .126 & .090 & $.278\left(^{* *}\right)$ & $.224\left(^{* *}\right)$ & $.182\left(^{*}\right)$ \\
\hline & $\begin{array}{c}\text { Sig } \\
\text { (two-tailed) }\end{array}$ & & .000 & .000 & .000 & .095 & .235 & .000 & .003 & .023 \\
\hline & $\mathrm{N}$ & 178 & 178 & 178 & 178 & 178 & 178 & 176 & 178 & 154 \\
\hline \multirow[t]{3}{*}{ Verbal } & Pearson & $.363\left(^{* *}\right)$ & 1 & $.414\left(^{* *}\right)$ & $.323\left(^{* *}\right)$ & $.351\left(^{* *}\right)$ & $.298\left(^{* *}\right)$ & $.421\left(^{* *}\right)$ & $\left..294^{(* *}\right)$ & $.469\left(^{* *}\right)$ \\
\hline & $\begin{array}{l}\text { Correlation sig } \\
\text { (two-tailed) }\end{array}$ & .000 & & .000 & .000 & .000 & .000 & .000 & .000 & .000 \\
\hline & $\mathrm{N}$ & 178 & 178 & 178 & 178 & 178 & 178 & 176 & 178 & 154 \\
\hline \multirow[t]{3}{*}{ Spatial } & $\begin{array}{c}\text { Pearson } \\
\text { Correlation Sig }\end{array}$ & $.460\left(^{* *}\right)$ & $.414\left(^{* *}\right)$ & 1 & $.509\left(^{* *}\right)$ & $.362\left(^{* *}\right)$ & $.281\left(^{* *}\right)$ & $.463\left(^{* *}\right)$ & $.365\left(^{* *}\right)$ & $.500\left(^{* *}\right)$ \\
\hline & (Two-tailed) & .000 & .000 & & .000 & .000 & .000 & .000 & .000 & .000 \\
\hline & $\mathrm{N}$ & 178 & 178 & 178 & 178 & 178 & 178 & 176 & 178 & 154 \\
\hline \multirow[t]{3}{*}{ Bodily } & $\begin{array}{l}\text { Pearson } \\
\text { correlation }\end{array}$ & $.309\left(^{* *}\right)$ & $.323\left(^{* *}\right)$ & $.509\left(^{* *}\right)$ & 1 & $.426\left(^{* *}\right)$ & $.456\left(^{* *}\right)$ & $.406\left(^{* *}\right)$ & $.436\left(^{* *}\right)$ & $.427\left(^{* *}\right)$ \\
\hline & $\begin{array}{c}\text { Sig } \\
\text { (two-tailed) }\end{array}$ & .000 & .000 & .000 & & .000 & .000 & .000 & .000 & .000 \\
\hline & $\mathrm{N}$ & 178 & 178 & 178 & 178 & 178 & 178 & 176 & 178 & 154 \\
\hline \multirow[t]{3}{*}{ Musical } & $\begin{array}{l}\text { Pearson } \\
\text { correlation }\end{array}$ & .126 & $.351\left(^{* *}\right)$ & $.362\left(^{* *}\right)$ & $.426\left(^{* *}\right)$ & 1 & $.433\left(^{* *}\right)$ & $.513\left(^{* *}\right)$ & $.322\left(^{* *}\right)$ & $.502\left(^{* *}\right)$ \\
\hline & $\begin{array}{c}\text { Sig } \\
\text { (two-tailed) }\end{array}$ & .095 & .000 & .000 & .000 & & .000 & .000 & .000 & .000 \\
\hline & $\mathrm{N}$ & 178 & 178 & 178 & 178 & 178 & 178 & 176 & 178 & 154 \\
\hline \multirow[t]{3}{*}{ Interpersonal } & $\begin{array}{l}\text { Pearson } \\
\text { correlation }\end{array}$ & .090 & $.298\left(^{* *}\right)$ & $.281\left(^{* *}\right)$ & $.456\left(^{* *}\right)$ & $.433\left(^{* *}\right)$ & 1 & $.485\left(^{* *}\right)$ & $.464\left(^{* *}\right)$ & $.399\left(^{* *}\right)$ \\
\hline & $\begin{array}{c}\text { Sig } \\
\text { (two-tailed) }\end{array}$ & .235 & .000 & .000 & .000 & .000 & & .000 & .000 & .000 \\
\hline & $\mathrm{N}$ & 178 & 178 & 178 & 178 & 178 & 178 & 176 & 178 & 154 \\
\hline \multirow[t]{3}{*}{ Intrapersonal } & $\begin{array}{l}\text { Pearson } \\
\text { correlation }\end{array}$ & $.278\left(^{* *}\right)$ & $.421\left(^{* *}\right)$ & $.463\left(^{* * *}\right)$ & $.406\left(^{* * *}\right)$ & $.513\left(^{* *}\right)$ & $.485\left(^{* *}\right)$ & 1 & $\left..3899^{* *}\right)$ & $.694\left(^{* *}\right)$ \\
\hline & $\begin{array}{c}\text { Sig } \\
\text { (two-tailed) }\end{array}$ & .000 & .000 & .000 & .000 & .000 & .000 & & .000 & .000 \\
\hline & $\mathrm{N}$ & 176 & 176 & 176 & 176 & 176 & 176 & 176 & 176 & 152 \\
\hline \multirow[t]{3}{*}{ Universal } & $\begin{array}{l}\text { Pearson } \\
\text { correlation }\end{array}$ & $.224\left(^{* *}\right)$ & $.294\left(^{* *}\right)$ & $.365\left(^{* *}\right)$ & $.436\left(^{* *}\right)$ & $.322\left(^{* *}\right)$ & $.464\left(^{* *}\right)$ & $.389\left(^{* *}\right)$ & 1 & $.358\left(^{* *}\right)$ \\
\hline & $\begin{array}{c}\text { Sig } \\
\text { (two-tailed) }\end{array}$ & .003 & .000 & .000 & .000 & .000 & .000 & .000 & & .000 \\
\hline & $\mathrm{N}$ & 178 & 178 & 178 & 178 & 178 & 178 & 176 & 178 & 154 \\
\hline \multirow[t]{3}{*}{ Existential } & $\begin{array}{l}\text { Pearson } \\
\text { correlation }\end{array}$ & $.182\left(^{*}\right)$ & $.469\left(^{* *}\right)$ & $.500\left(^{* *}\right)$ & $.427\left(^{* * *}\right)$ & $.502\left(^{* *}\right)$ & $.399\left(^{* *}\right)$ & $.694\left(^{* *}\right)$ & $.358\left(^{* *}\right)$ & 1 \\
\hline & $\begin{array}{c}\text { Sig } \\
\text { (two-tailed) }\end{array}$ & .023 & .000 & .000 & .000 & .000 & .000 & .000 & .000 & \\
\hline & $\mathrm{N}$ & 154 & 154 & 154 & 154 & 154 & 154 & 152 & 154 & 154 \\
\hline
\end{tabular}

${ }^{* *} p<.01 .{ }^{*} p<.05$. 
Table 8. Regression analysis of MI predicting AT, english scores and levels.

\begin{tabular}{|c|c|c|c|c|c|c|}
\hline \multirow{2}{*}{ Variable } & \multicolumn{2}{|c|}{ AT } & \multicolumn{2}{|c|}{ English score } & \multicolumn{2}{|c|}{ English level } \\
\hline & $\mathrm{t}$ & sig & $\mathrm{t}$ & sig & $\mathrm{t}$ & sig \\
\hline (Constant) & 8.478 & .000 & -.262 & .796 & 4.375 & .000 \\
\hline Logical/mathematical intelligence & 3.346 & .001 & -.197 & .845 & -.650 & .518 \\
\hline Verbal/linguistic intelligence & -2.417 & .017 & .001 & .999 & .135 & .893 \\
\hline Visual/spatial intelligence & -2.562 & .011 & -.216 & .830 & -1.111 & .270 \\
\hline Bodily intelligence & 1.767 & .079 & .114 & .910 & -.283 & .778 \\
\hline Musical/rhythmic intelligence & 1.627 & .106 & 1.236 & .227 & .274 & .785 \\
\hline Interpersonal intelligence & -.035 & .972 & .016 & .988 & -1.475 & .144 \\
\hline Intrapersonal intelligence & .055 & .956 & -1.601 & .122 & 1.146 & .255 \\
\hline Universal/naturalist intelligence & -.644 & .521 & .724 & .476 & 1.716 & .090 \\
\hline Existential intelligence & 1.500 & 1.36 & 2.741 & .011 & .136 & .892 \\
\hline
\end{tabular}

Table 9. Subcategories of Second Language Tolerance of Ambiguity Scale (SLTAS).

\begin{tabular}{|c|c|c|c|c|c|c|}
\hline & $\mathrm{N}$ & Min & Max & M & SD & rank \\
\hline Listening & 178 & 1.00 & 4.00 & 2.7753 & .74792 & (4) \\
\hline Speaking & 178 & 1.00 & 4.00 & 2.7247 & .84877 & (5) \\
\hline Reading & 178 & 1.00 & 4.00 & 2.4888 & .56487 & (7) \\
\hline Writing & 178 & 1.00 & 4.00 & 2.9101 & .68090 & (1) \\
\hline Lexical development & 178 & 1.00 & 4.00 & 2.6180 & .64887 & (6) \\
\hline Grammar & 178 & 1.00 & 4.00 & 2.8371 & .62786 & (2) \\
\hline Pronunciation & 178 & 1.00 & 4.00 & 2.8090 & .91906 & (3) \\
\hline All SLAT & 178 & 1.00 & 4.00 & 2.7088 & .51904 & \\
\hline
\end{tabular}

*In the study, the higher the score, the lower the tolerance of ambiguity.

\subsection{Regression Analysis of MI, AT, and Gender Predicting English Scores and Levels}

A standard regression analysis was performed between the dependent variables (English scores and English levels) and independent variables (gender, AT, and MI). The analysis was performed using SPSS regression.

Findings showed that among the three variables of multiple intelligences, tolerance of ambiguity, and English scores or English levels, only tolerance of ambiguity was negatively predictive to both English scores $(\mathrm{t}=-2.215$, $p<.05)$ and English levels ( $\mathrm{t}=-2.908, p<.01)$, but both multiple intelligences and gender were not. The findings were presented in Table 15.

\subsection{Correlation among Subcategories of MI, AT and English Scores/Levels}

By analyzing the subcategories of MI and AT, predicting to English scores and levels, findings showed that correlation among subcategories of MI, AT, and English scores did exist in one way or another. It was shown that on the one hand, some subcategories of multiple intelligences were predictive to some of subcategories of tolerance of ambiguity and English scores as well, on the other hand, some subcategory of tolerance of ambiguity was predictive to English scores. More specifically, Logical intelligence was predictive to speaking $(\mathrm{t}=4.149$, $\mathrm{sig}=.000)$, reading $(\mathrm{t}=2.652$, sig $=.009)$, lexical development $(\mathrm{t}=3.277$, sig $=.001)$, and grammar $(\mathrm{t}=2.682$, $\mathrm{sig}=.008)$. In addition, Linguistic intelligence was negatively predictive to speaking $(\mathrm{t}=-2.635$, sig $=.009)$, 
Table 10. Co-relation among subcategories of tolerance of ambiguity.

\begin{tabular}{|c|c|c|c|c|c|c|c|c|}
\hline & & Listening & Speaking & Reading & Writing & Lexical development & Grammar & Pronunciation \\
\hline \multirow[t]{3}{*}{ Listening } & Pearson correlation & 1 & $.445\left(^{* *}\right)$ & $.627\left(^{* *}\right)$ & $.615\left(^{* *}\right)$ & $.468\left(^{* *}\right)$ & $.475\left(^{* *}\right)$ & $.406\left(^{* *}\right)$ \\
\hline & Sig (two-tailed) & & .000 & .000 & .000 & .000 & .000 & .000 \\
\hline & $\mathrm{N}$ & 178 & 178 & 178 & 178 & 178 & 178 & 178 \\
\hline \multirow[t]{3}{*}{ Speaking } & Pearson correlation & $.445\left(^{* *}\right)$ & 1 & $.479\left(^{* *}\right)$ & $.431\left(^{* *}\right)$ & $.577\left(^{* *}\right)$ & $.467\left(^{* *}\right)$ & $.432\left(^{* *}\right)$ \\
\hline & Sig (two-tailed) & .000 & & .000 & .000 & .000 & .000 & .000 \\
\hline & $\mathrm{N}$ & 178 & 178 & 178 & 178 & 178 & 178 & 178 \\
\hline \multirow[t]{3}{*}{ Reading } & Pearson correlation & $.627\left(^{* *}\right)$ & $.479\left(^{* *}\right)$ & 1 & $.524\left(^{* *}\right)$ & $.648\left(^{* *}\right)$ & $.499\left(^{* *}\right)$ & $.413\left({ }^{* * *}\right)$ \\
\hline & Sig (two-tailed) & .000 & .000 & & .000 & .000 & .000 & .000 \\
\hline & $\mathrm{N}$ & 178 & 178 & 178 & 178 & 178 & 178 & 178 \\
\hline \multirow[t]{3}{*}{ Writing } & Pearson correlation & $.615\left(^{* *}\right)$ & $.431\left(^{* *}\right)$ & $.524\left(^{* *}\right)$ & 1 & $.491\left(^{* *}\right)$ & $.623\left(^{* *}\right)$ & $.492\left(^{* *}\right)$ \\
\hline & Sig (two-tailed) & .000 & .000 & .000 & & .000 & .000 & .000 \\
\hline & $\mathrm{N}$ & 178 & 178 & 178 & 178 & 178 & 178 & 178 \\
\hline \multirow[t]{3}{*}{ Lexical devel } & Pearson correlation & $.468\left(^{* *}\right)$ & $.577\left(^{* *}\right)$ & $.648\left(^{* *}\right)$ & $.491\left(^{* *}\right)$ & 1 & $.540\left(^{* *}\right)$ & $.450\left(^{* *}\right)$ \\
\hline & Sig (two-tailed) & .000 & .000 & .000 & .000 & & .000 & .000 \\
\hline & $\mathrm{N}$ & 178 & 178 & 178 & 178 & 178 & 178 & 178 \\
\hline \multirow[t]{3}{*}{ Grammar } & Pearson correlation & $.475\left(^{* *}\right)$ & $.467\left(^{* *}\right)$ & $.499\left(^{* *}\right)$ & $.623\left(^{* *}\right)$ & $.540\left(^{* *}\right)$ & 1 & $.430\left(^{* *}\right)$ \\
\hline & Sig (two-tailed) & .000 & .000 & .000 & .000 & .000 & & .000 \\
\hline & $\mathrm{N}$ & 178 & 178 & 178 & 178 & 178 & 178 & 178 \\
\hline \multirow[t]{3}{*}{ Pronunciation } & Pearson correlation & $.406\left(^{* *}\right)$ & $.432\left(^{* *}\right)$ & $.413\left(^{* *}\right)$ & $.492\left(^{* *}\right)$ & $.450\left(^{* *}\right)$ & $.430\left(^{* *}\right)$ & 1 \\
\hline & Sig (two-tailed) & .000 & .000 & .000 & .000 & .000 & .000 & \\
\hline & $\mathrm{N}$ & 178 & 178 & 178 & 178 & 178 & 178 & 178 \\
\hline
\end{tabular}

${ }^{* *} p<.01$ (two-tailed).

Table 11. Regression analysis of AT predicting english scores and levels.

\begin{tabular}{|c|c|c|c|c|}
\hline \multirow{2}{*}{ Variable } & \multicolumn{2}{|c|}{ English score } & \multicolumn{2}{|c|}{ English level } \\
\hline & $\mathrm{t}$ & sig & $\mathrm{t}$ & sig \\
\hline (Constant) & 8.022 & .000 & 10.181 & .000 \\
\hline Listening & .805 & .425 & .063 & .950 \\
\hline Speaking & -1.369 & .179 & -.340 & .735 \\
\hline Reading & -3.025 & .004 & -1.693 & .094 \\
\hline Writing & -.951 & .347 & .796 & .428 \\
\hline Lexical development & 1.061 & .295 & .538 & .592 \\
\hline Grammar & .217 & .829 & -.817 & .416 \\
\hline Pronunciation & .132 & .896 & -1.267 & .208 \\
\hline
\end{tabular}

${ }^{* *} p<.01 .{ }^{*} p<.05$. 
Table 12. Gender differences of Multiple Intelligences (MI).

\begin{tabular}{|c|c|c|c|c|c|}
\hline Variable & Gender & $\mathrm{N}$ & M & SD & Sig \\
\hline \multirow{2}{*}{ Visual/spatial intelligence } & Male & 53 & 2.95 & .84 & \multirow{2}{*}{.088} \\
\hline & Female & 125 & 2.75 & .67 & \\
\hline \multirow{2}{*}{ Verbal/linguistic intelligence } & Male & 53 & 3.14 & .79 & \multirow{2}{*}{.462} \\
\hline & Female & 125 & 3.22 & .64 & \\
\hline \multirow{2}{*}{ Visual/spatial intelligence } & Male & 53 & 3.43 & .78 & \multirow{2}{*}{.774} \\
\hline & Female & 125 & 3.40 & .68 & \\
\hline \multirow{2}{*}{ Bodily intelligence } & Male & 53 & 3.25 & .76 & \multirow{2}{*}{.020} \\
\hline & Female & 125 & 2.97 & .71 & \\
\hline \multirow{2}{*}{ Musical/rhythmic intelligence } & Male & 53 & 3.44 & .84 & \multirow{2}{*}{.367} \\
\hline & Female & 125 & 3.57 & .86 & \\
\hline \multirow{2}{*}{ Interpersonal intelligence } & Male & 53 & 3.28 & .79 & \multirow{2}{*}{.232} \\
\hline & Female & 125 & 3.13 & .69 & \\
\hline \multirow{2}{*}{ Intrapersonal intelligence } & Male & 52 & 3.52 & .78 & \multirow{2}{*}{.359} \\
\hline & Female & 124 & 3.42 & .57 & \\
\hline \multirow{2}{*}{ Universal/naturalist intelligence } & Male & 53 & 3.03 & .85 & \multirow{2}{*}{.004} \\
\hline & Female & 125 & 2.69 & .65 & \\
\hline \multirow{2}{*}{ Existential intelligence } & Male & 45 & 3.85 & .90 & \multirow{2}{*}{.251} \\
\hline & Female & 109 & 3.69 & .68 & \\
\hline \multirow{2}{*}{ All MI logical/mathematical intelligence } & Male & 44 & 3.32 & .65 & \multirow{2}{*}{.256} \\
\hline & Female & 108 & 3.22 & .41 & \\
\hline
\end{tabular}

Table 13. Gender differences of tolerance of Ambiguity (AT).

\begin{tabular}{|c|c|c|c|c|c|}
\hline Variable & Gender & $\mathrm{N}$ & M & SD & Sig \\
\hline \multirow[b]{2}{*}{ Listening } & Male & 53 & 2.54 & .74 & \multirow[b]{2}{*}{.008} \\
\hline & Female & 125 & 2.87 & .72 & \\
\hline \multirow{2}{*}{ Speaking } & Male & 53 & 2.69 & .86 & \multirow{2}{*}{.786} \\
\hline & Female & 125 & 2.73 & .84 & \\
\hline \multirow{2}{*}{ Reading } & Male & 53 & 2.39 & .54 & \multirow{2}{*}{.155} \\
\hline & Female & 125 & 2.52 & .56 & \\
\hline \multirow{2}{*}{ Writing } & Male & 53 & 2.83 & .69 & \multirow{2}{*}{.309} \\
\hline & Female & 125 & 2.94 & .67 & \\
\hline \multirow{2}{*}{ Lexical development } & Male & 53 & 2.49 & .63 & \multirow{2}{*}{.088} \\
\hline & Female & 125 & 2.67 & .64 & \\
\hline \multirow{2}{*}{ Grammar } & Male & 53 & 2.77 & .59 & \multirow{2}{*}{.366} \\
\hline & Female & 125 & 2.86 & .64 & \\
\hline \multirow[b]{2}{*}{ Pronunciation } & Male & 53 & 2.71 & .92 & \multirow[b]{2}{*}{.389} \\
\hline & Female & 125 & 2.84 & .91 & \\
\hline \multirow{2}{*}{ All AT } & Male & 53 & 2.61 & .49 & \multirow{2}{*}{.104} \\
\hline & Female & 125 & 2.75 & .52 & \\
\hline
\end{tabular}


Table 14. Gender differences of english scores and levels.

\begin{tabular}{cccccc}
\hline Variable & Gender & N & M & SD & Sig \\
\hline \multirow{2}{*}{ English scores } & Male & 12 & 36.04 & 8.34 & .209 \\
& Female & 36 & 31.38 & 11.66 & \\
English levels & Male & 30 & 8.06 & 1.69 & .583 \\
& Female & 74 & 7.82 & 2.16 &
\end{tabular}

Table 15. Regression analysis of MI, AT, and gender predicting english scores and levels.

\begin{tabular}{cccccc}
\hline \multirow{2}{*}{ Variable } & \multicolumn{2}{c}{ English score } & \multicolumn{2}{c}{ English level } \\
\cline { 2 - 6 } (Constant) & $\mathrm{T}$ & $\mathrm{sig}$ & $\mathrm{t}$ & Sig \\
\hline Multiple intelligences & 2.127 & .041 & 5.170 & .000 \\
Second Language Tolerance of Ambiguity & .594 & .557 & -.147 & .884 & .006 \\
Gender & -2.215 & .034 & -2.908 & .016 & .987 \\
\hline
\end{tabular}

${ }^{* *} p<.01 .{ }^{*} p<.05$.

lexical development $(\mathrm{t}=-2.090$, sig $=.038)$, and grammar $(\mathrm{t}=-2.172$, sig $=.032)$, while Visual intelligence was negatively predictive to speaking $(t=-1.986$, sig $=.049)$, reading $(t=-2.389$, sig $=.018)$, lexical development $(\mathrm{t}=-2.738$, sig $=.007)$, and grammar $(\mathrm{t}=-1.986$, sig $=.049)$, Bodily intelligence was predictive to reading $(\mathrm{t}=2.389$, sig $=.018)$, and lexical development $(\mathrm{t}=2.412$, sig $=.017)$, Musical intelligence was predictive to reading $(t=2.655$, sig $=.009)$, and Existential intelligence was predictive to grammar $(t=1.989$, sig $=.049)$ and English score $(\mathrm{t}=2.741$, sig $=.011)$. On the other hand, Tolerant of ambiguity of Reading (AT reading) was negatively predictive to English scores $(\mathrm{t}=-2.159$, sig $=.037)$.

The correlation among multiple intelligences, tolerance of ambiguity and English scores was shown in Figure 1, and the conclusion was shown in Figure 2.

\section{Conclusions}

Conclusion included summary and discussion, implication and limitations. They were described below:

\subsection{Summary and Discussion}

The study aimed to investigate 1) if there was a correlation among Taiwanese EFL leaners' multiple intelligences, tolerance of ambiguity and the effect on their English learning and 2) gender differences in multiple intelligences, tolerance of ambiguity and English learning performance. A total of 178 college English majors served as subjects of the study, including 50 males and 128 females. They helped to fill out the questionnaires of Multiple Intelligences (MI) (Gardner, 1983) and Second Language Tolerance of Ambiguity Scale (SLTAS) (Ely, 1995) (English-Chinese version). In addition, their English scores or/and levels of College Entrance Exam were adopted as their English proficiency. Furthermore, descriptive analysis, t-Test, ANOVA, and regression analysis were analyzed by the Statistical Package for the Social Science (SPSS).

The findings revealed that students were stronger with those intelligences as Existential Intelligence $\left(1^{\text {st }}\right)$, Musical/Rhythmic Intelligence $\left(2^{\text {nd }}\right)$, Intrapersonal Intelligence (3rd), and Visual/Spatial Intelligence $\left(4^{\text {th }}\right)$, and Verbal/ Linguistic Intelligence $\left(5^{\text {th }}\right)$. On the other hand, they were weaker with Interpersonal Intelligences $\left(6^{\text {th }}\right)$. Bodily Intelligence $\left(7^{\text {th }}\right)$, Logical/Mathematical Intelligence $\left(8^{\text {th }}\right)$, and Universal/Naturalist Intelligence $\left(9^{\text {th }}\right)$. The findings were quite different from that of Mexican learners conducted by Carlin et al. (2013), where the highest kinds of intelligences were Bodily/Kinesthetic, Interpersonal, Intrapersonal, and Musical; while the lowest ones were Naturalist, Existential, Verbal/Linguistic, Logical/Mathematic and Visual/Spatial.

In addition, students were regarded as Moderate tolerant of ambiguity $(M=2.70$ out of 4.00$)$. They were more tolerant of ambiguity in "receptive" areas, particularly in reading $(\mathrm{M}=2.48, \mathrm{SD}=.56)$, and less tolerant of 


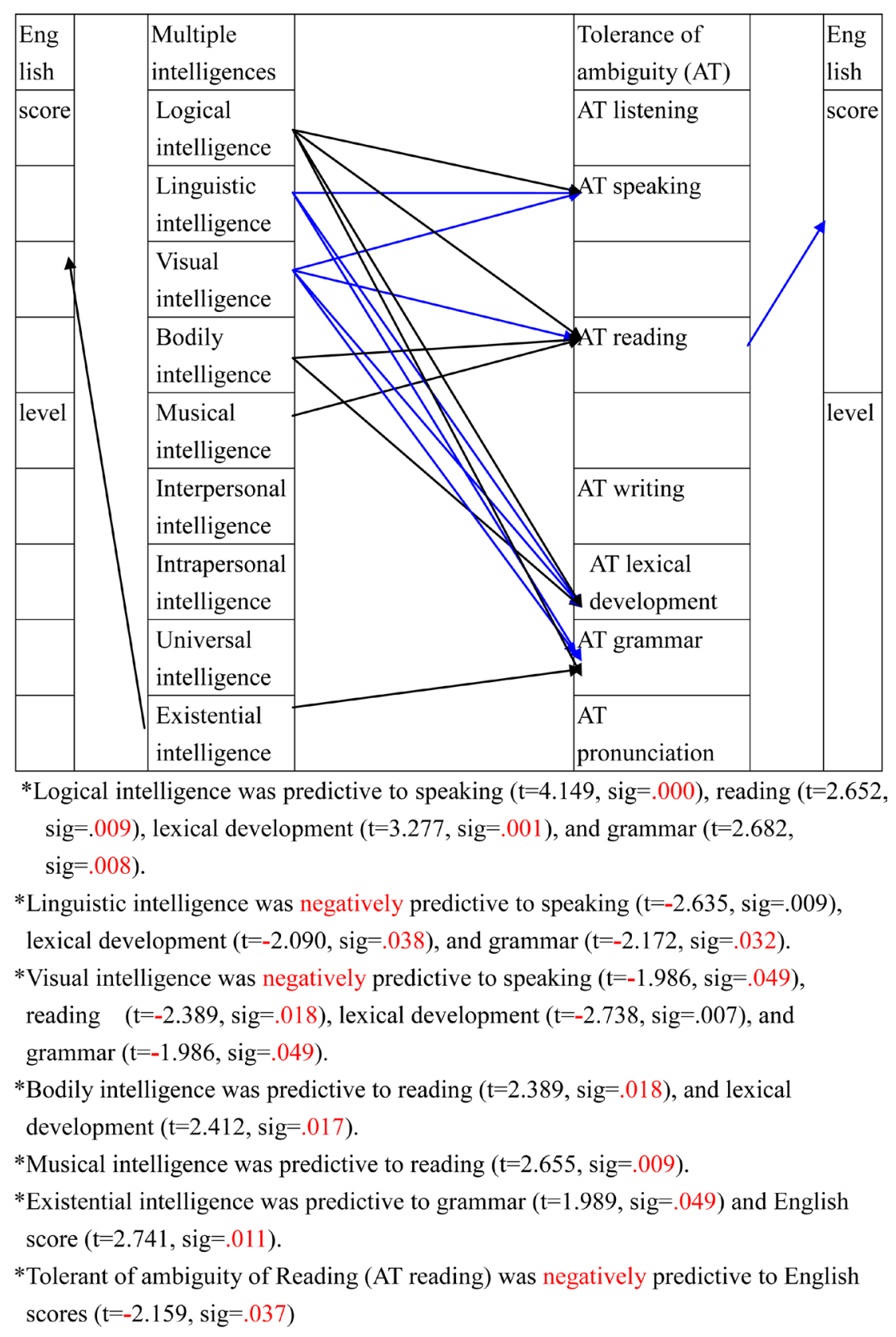

Figure 1. Correlation among multiple intelligences, ambiguity tolerance and english.

ambiguity in "productive" skills, especially in writing $(\mathrm{M}=2.91, \mathrm{SD}=.68)$ (in the study, the higher the score, the lower the tolerance of ambiguity). As the 12-item SLTAS could be divided into 7 language components, based on the results, we could understand why our students felt more uncomfortable in facing the uncertainty, lacking of determinacy dwarfed by that inherent in writing $\left(1^{\text {st }}\right)$, grammar $\left(2^{\text {nd }}\right)$, and pronunciation $\left(3^{\text {rd }}\right)$. Comparatively, since they were in an EFL situation, students were more tolerant of ambiguity in reading $\left(7^{\text {th }}\right)$, lexical development $\left(6^{\text {th }}\right)$, speaking $\left(5^{\text {th }}\right)$, and listening $\left(4^{\text {th }}\right)$. The results were keeping with some other studies conducted in EFL fields, such as Karamia (1999), Kamran (2011), and Marzban et al. (2012).

The study found that a correlation among multiple intelligences, tolerance of ambiguity, and English proficiency did exist. Some subcategories of multiple intelligences (such as Logical intelligences, Linguistic intelligences, Visual intelligence, Bodily intelligence, and Existential intelligence) were predictive to tolerance of ambiguity either positively or negatively, and led to English proficiency at the end. 


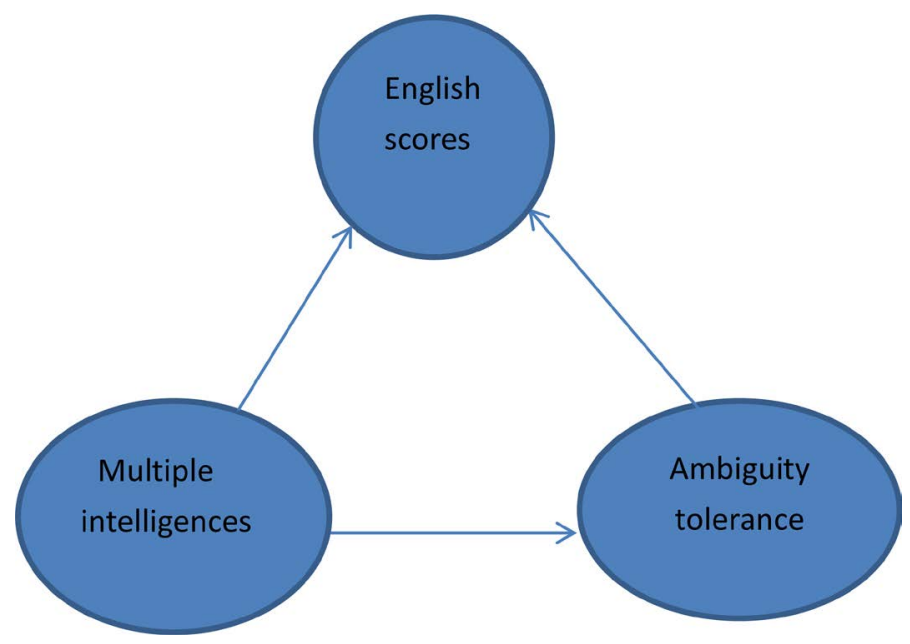

Figure 2. Correlation among MI, AT, and English.

Regarding to gender differences, males tended to have higher Bodily intelligence $(p<.05)$ and Universal intelligence $(p<.01)$. In addition, males had higher means in English scores and levels, but lower means in all components of tolerance of ambiguity. In other words, males had better English proficiency and more tolerant of ambiguity than females. Though, the differences didn't reach significant level, yet by an item-by-item analysis, males were found to be more tolerant of ambiguity in listening $(p<.01)$. Hence, females seemed to be less tolerant of ambiguity in English learning than males, especially in listening $(p<.01)$. That males were more tolerant of ambiguity was supported by many studies, and it was also reported that males were more field-independent than females and therefore could identify details from confusing backgrounds more effectively than females (Oxford, 2003). However, though females were less tolerant of ambiguity, not very capable of seeing details from confusing background and considering details before making a decision in incomplete and uncertain situations in language learning, yet, that may cause them to hold more favorable learning attitude and motivational intensity, using more appropriate strategies to have better achievement than their male peers. That could explain why females were always proved to be better language learners (Oxford, 2003; Cheng et al., 2010).

All came to the answer to the question if good language learners were stronger with Verbal/Linguistic intelligence and more tolerant of ambiguity. Clearly, in the study, the answer was negative. But one thing also clear was that second/foreign learning is really "a multi-faceted task" (Chapelle \& Roberts, 1986: p. 44), and to be a successful language learner, in addition to stronger Verbal/Linguistic intelligences, more tolerance of ambiguity, such "predispositions" (Jamieson, 1992) as motivation, attitude, anxiety, field dependence/independence, cognitive styles and learning strategies, all still need to be taken into account.

\subsection{Implications}

The results of the investigation of the correlation among multiple intelligences, tolerance of ambiguity, and English proficiency could be used to help students be familiar with their multiple intelligences, and be aware of the existence of uncertainty in language learning situation. Also, the findings could be used to convince students to become more interested in developing more favorable attitude and motivational intensity. By so doing, students may make the best use of their intelligence strengths, use more language learning strategies, become more tolerant of ambiguity, interpret unclear information more properly and become less anxious in foreign language learning. As for teachers, it is hoped that teachers can play the role as a "language coach" (Cohen, 2003), to provide all students equal opportunities to use their strengths to learn. In addition, teachers should act as active agents in the learning process to help students not only to awaken, amplify, learn, and transfer the intelligences (Christison, 1998) but also to know that language learning is anxiety-provoking, and a little ambiguity can go a long if curriculum design, teaching activities, and appropriate evaluation be provided and met.

\subsection{Limitations of the Study}

There were three limitations of the study. First, the sample size did not have a good balance of males and fe- 
males (50:128), which may influence the results of gender differences. Second, as mentioned in the procedure, about one third of the subjects didn't want to write their names on the answer sheets, which caused no way to find their English scores/levels from files, and the intention to investigate the factors related to students' English proficiency was limited. Third, students might not be serious enough to fill out the questionnaire, which might influence the result to some extent.

\section{References}

Akbari, R., \& Hosseini, K. (2008). Multiple Intelligences and Language Learning Strategies: Investigating Possible Relations. System, 36, 141-155. http://dx.doi.org/10.1016/j.system.2007.09.008

Armstrong, T. (2000). Multiple Intelligences in the Classroom. The Association for Supervision and Curriculum Development (ASCD).

Arnold, J., \& Fonseca, C. (2004). Multiple Intelligence Theory and Foreign Language Learning: A Brain-Based Perspective. International Journal of English Studies, 4, 119-136.

Bu, L. N. (2007). The Influence of Ambiguity Tolerance on Chinese College Students during Their English Learning. Unpublished MA Thesis, Xi'an: Xi'an Electronics and Technology University.

Budner, S. (1962). Intolerance of Ambiguity as a Personality Variable. Journal of Personality, 30, 29-50. http://dx.doi.org/10.1111/j.1467-6494.1962.tb02303.x

Chapelle, C. (1983). The Relationship between Ambiguity Tolerance and Success in Acquiring English as a Second Language in Adult Learners. Unpublished Doctoral Dissertation, Champaign, IL: University of Illinois at Urbana-Champaign.

Chapelle, C., \& Roberts, C. (1986). Ambiguity Tolerance and Field Independence as Predictors of Proficiency in English as a Second Language. Language Learning, 36, 27-45. http://dx.doi.org/10.1111/j.1467-1770.1986.tb00367.x

Chen, L. J. (1989). Some Important Characteristics of Good Language Learners-A Study of Cadets from the Chinese Military Academy. A Paper for the Promotion of an Associate Professor, the Chinese Military Academy.

Cheng, H. Y., Lee, F. M., Liou, P. P., \& Chung, W. Y. (2010). Are Females Better Language Learners? WHAMPOA—An Interdisciplinary Journal, 59, 55-72.

Christison, M. A. (1996). Teaching and Learning Languages through Multiple Intelligences. TESOL Journal, 6, 10-14.

Christison, M. A. (1998). An Introduction to Multiple Intelligence Theory and Second Language Learning. In J. M. Reid (Ed.), Understanding Learning Styles in the Second Language Classroom (pp. 1-14). Upper Saddle River, NJ: Prentice Hall Regents.

College Entrance Advanced Subject Test (CEAST) (2015). www.ceec.edu.tw/CeecIntro/CeecEnglishProfile.htm

College Entrance Examination (CEE) (2015). www.ceec.edu.tw/CeecIntro/CeecEnglishProfile.htm

Del Mar Palenzuela Perez, M., \& Ruz, N. R. (2014). Intrapersonal Intelligence and Motivation in Foreign Language Learning. European Scientific Journal, 10, 142-150.

Dornyei, Z. (1994). Motivation and Motivating in the Foreign Language Classroom. The Modern Language Journal, 78, 273-284. http://dx.doi.org/10.1111/j.1540-4781.1994.tb02042.x

Du, Z. M. (2006). Enlightenment of Ambiguity Tolerance and Schema Theory on College English Listening Teaching. Journal of the Chinese People's Armed Police Force Academy, 22, 43-45.

Ehrlich, D. (1965). Intolerance of Ambiguity. Walk’s A Scale: Historical Comment. Psychological Reports, 17, $591-595$. http://dx.doi.org/10.2466/pr0.1965.17.2.591

Ehrman, M. (1994). Weakest and Strongest Learners in Intensive Language Training: A Case Study of Extremes. In C. A. Klee (Ed.), Faces in a Crowd: The Individual Learner in Multisection Courses (pp. 81-118). Boston, MA: Heinle \& Heinle.

Ehrman, M. (1999). Ego Boundaries and Tolerance of Ambiguity in Second Language Learning. In J. Arnold (Ed.), Affect in Language Learning (pp. 68-86). Cambridge: Cambridge University Press.

El-Koumy, A. S. A. (2000). Differences in EF Reading Comprehension among High-, Middle-, and Low-Ambiguity Tolerance Students. The National Symposium on English Language Teaching in Egypt, Ain Shams University, Egypt, 21-23 March 2000. Eric Document. ED 445534.

Ely, C. M. (1986). An Analysis of Discomfort, Risk-Taking, Sociability, and Motivation in the L2 Classroom. Language Learning, 36, 1-25. http://dx.doi.org/10.1111/j.1467-1770.1986.tb00366.x

Ely, C. M. (1989). Tolerance of Ambiguity and Use of Second Language Strategies. Foreign Language Annals, 22, 437-445. http://dx.doi.org/10.1111/j.1944-9720.1989.tb02766.x

Ely, C. M. (1995). Tolerance of Ambiguity and the Teaching of ESL. In J. M. Reid (Ed.), Learning Styles in the ESL/EFL 
Classroom (pp. 87-95). New York: Heinle \& Heinle Publishers.

Erten, I., \& Topkaya, E. (2009). Understanding Tolerance of Ambiguity of EFL Learners in Reading Classes. At Tertiary Level. Novitas-ROYAL, 3, 29-44.

Etzel, B. C. (1953). A Study of the Effects of Frustration upon the Preference for Doing a Subsequent Task. Unpublished Doctoral Dissertation, Iowa City, IA: State University of Iowa.

Frenkel-Brunswik, E. (1949). Intolerance of Ambiguity as an Educational and Perceptual Personality Variable. Journal of Personality, 18, 108-143. http://dx.doi.org/10.1111/j.1467-6494.1949.tb01236.x

Fukuchi, N. T., \& Sakamoto, R. (2005). Affective Dimensions of the Japanese Foreign Language Learner: Implications for Psychological Learner Development in Japan. Journal of Multilingual and Multicultural Development, 26, 333-350. http://dx.doi.org/10.1080/01434630508669086

Gardner, Howard. (1983). Frames of Mind: The Theory of Multiple Intelligences. New York: Basic Books.

Gardner, Howard. (1993). Multiple Intelligences: The Theory in Practice. New York: Basic Books.

Gardner, Howard. (1999). Intelligence Reframed. New York: Basic Books.

Gardner, Howard. (2000). The Disciplined Mind: Beyond Facts and Standardized Tests, the K-12 Education that Every Child Deserves. New York: Penguin Putnam.

Gardner, Howard. (2003). Multiple Intelligences after Twenty Years. Chicago, IL: The American Educational Research Association.

Gay, L. R., \& Airasian, P. (2003). Educational Research: Competencies for Analysis and Applications (7th ed.). Upper Saddle River, NJ: Merrill Prentice Hall.

Horwitz, E. (1988). The Beliefs about Language Learning of Beginning University Students. The Modern Language Journal, 72, 182-193. http://dx.doi.org/10.1111/j.1540-4781.1988.tb04190.x

Horwitz, E. K., Horwitz, M. B., \& Cope, J. (1986). Foreign Language Classroom Anxiety. The Modern Language Journal, 70, 125-132. http://dx.doi.org/10.1111/j.1540-4781.1986.tb05256.X

Hou, Y.-A., Hou, Y.-J., \& Cheng, H.-Y. (2015). Analysis of Some Factors Predicting Students' English Performance. Journal of National United University, 12, 17-42.

Hou, Y.-J., \& Cheng, H.-Y. (2014). The Nine Intelligences and Six Learning Styles in College Students' Academic Performance-A Case Study. Journal of National United University, 11, 35-62.

Jafari, Z., Yavari, S., \& Shokri, M. (2015). The Impact of Self-Assessment of EFL Learners' Tolerance of Ambiguity. International Journal of Language and Linguistics, 3, 271-274. http://dx.doi.org/10.11648/j.jjll.20150304.22

Jamieson, J. (1992). The Cognitive Styles of Reflection/Impulsivity and Fields Independence/Dependence and ESL Success. The Modern Language Journal, 76, 491-501. http://dx.doi.org/10.1111/j.1540-4781.1992.tb05398.x

Kamran, S. K. (2011). Effects of Gender on Ambiguity Tolerance of Iranian English Language Learners. Journal of Education and Practice, 2, 25-33.

Khajeh, A. (2002). The Relationship between Tolerance of Ambiguity, Gender, Level of Proficiency and Use of Second Language Learning Strategies. Unpublished MA Thesis, Tehran: Tarbiat Modares University.

Kim, I.-S. (2009). The Relevance of Multiple Intelligences to CALL Instruction. The Reading Matrix, 9, 1-21.

Kondo-Brown, K. (2006). Affective Variables and Japanese L2 Reading Ability. Reading in a Foreign Language, 18 , 55-71.

Lai, P. (2009). The Necessity of Studying Learners' Tolerance of Ambiguity in Foreign Language Education. Forum on Chinese Culture, 7, 287-289.

Lee, H. Y. (1998). Language Learning Strategies and Tolerance of Ambiguity of Korean Midshipmen Learning English as a Foreign Language. Unpublished Doctoral Dissertation, Muncie, IN: Ball State University.

Levitt, E. E. (1953). Studies in Intolerance of Ambiguity: The Decision Location Test with Grade School Children. Child Development, 24, 263-268. http://dx.doi.org/10.1111/j.1467-8624.1953.tb04732.x

Li, E. L. (2007). A Study of Non-English Majors’ Differences in Tolerance of Ambiguity by Gender and Proficiency. Unpublished MA Thesis, Jiangxi: Jiangxi Normal University.

Li, M. Y. (2010). The Impacts of Ambiguity Tolerance on Reading Comprehension of English Majors. Journal of Hubei University of Economics (Humanities and Social Science), 7, 198-199.

Liu, C. (2015). Relevant Researches on Tolerance of Ambiguity. Theory and Practice in Language Studies, 5, $1874-1882$. http://dx.doi.org/10.17507/tpls.0509.15

Liu, F. (2006). Ambiguity Tolerance in Chinese Students of College English. Asian Social Science, 2, 96-99.

Liu, M. (2011). A Survey on the Relationship between Tolerance of Ambiguity and English Reading Comprehension Performance of Three-Year English Majors in College. Foreign Language Teaching and Research, 12, 116-117. 
MacDonald, A. P. (1970). Revised Scale for Ambiguity Tolerance: Reliability and Validity. Psychological Reports, 25, 791798. http://dx.doi.org/10.2466/pr0.1970.26.3.791

Marzban, A., Barati, H., \& Moinzadeh, A. (2012). An Investigation into Ambiguity Tolerance in Iranian Senior EFL Undergraduates. English Language Teaching, 5, 76-85.

McKenzie, W. (2004). Multiple Intelligences and Instructional Technology. http://surfaquarium.com

McLain, D. L. (1993). The MSTAT-1: A New Measurement of an Individual's Tolerance for Ambiguity. Educational and Psychological Measurement, 53, 183-189. http://dx.doi.org/10.1177/0013164493053001020

Naiman, N., Frohlich, M., \& Stern, H. H. (1975). The Good Language Learner. The Ontario Institute for Studies in Education.

Norton, R. W. (1975). Measurement of Ambiguity Tolerance. Journal of Personality Assessment, 39, 607-619. http://dx.doi.org/10.1207/s15327752jpa3906_11

O’Connor, P. (1952). Ethnocentrism, Intolerance of Ambiguity and Abstract Reasoning Ability. Journal of Abnormal and Social Psychology, 47, 526-530. http://dx.doi.org/10.1037/h0056142

Oxford, R. L. (1995). Gender Differences in Language Learning Styles: What Do They Mean? In J. M. Reid (Ed.), Learning Styles in the ESL/EFL Classroom (pp. 34-46). Boston, MA: Heinle \& Heinle Publishers.

Oxford, R. L. (2003). Language Learning Styles and Strategies: An Overview. GALA, 1-25.

Pimsleur, P., Sundland, D., \& McIntyre, R. (1966). Underachievement in Foreign Language Learning. New York: MLA Materials Center.

Reid, J. M. (1998). Understanding Learning Styles in the Second Language Classroom. Upper Saddle River, NJ: Prentice Hall Regents.

Reid, J. M. (Ed.) (1995). Learning Styles in the ESL/EFL Classroom. Boston, MA: Heinle \& Heinle Publishers.

Richards, J., \& Rodgers, T. (2001). Approaches and Methods in Language Teaching. Cambridge: Cambridge University Press. http://dx.doi.org/10.1017/CBO9780511667305

Rostami, S. (2010). The Relationship between Emotional Intelligence and EFL Learners' Language Learning Strategy use. Unpublished MA Thesis, Tehran: Islamic Azad University of Central at Tehran Branch.

Saeidi, M., \& Karvandi, F. (2014). The Relationship between EFL Learners’ Multiple Intelligences and Their Performance on Reason-Gap Writing Task. International Journal of Language Learning and Applied Linguistics World (IJLLALW), 5, 189-202.

Shayeghi, R., \& Hosseinioun, P. (2015). The Relationship between Iranian EFL Learners’ Multiple Intelligences and Their Performance on Grammar Tests. International Scholarly and Science Research \& Innovation, 9, 2972-2976.

Shearer, B. (1996). Multiple Intelligences Developmental Assessment Scale. Dayton, OH: Greyden Press.

Stake, R. E. (1988). Case Study Methods in Educational Research: Seeking Sweet Water. In R. M. Jaeger (Ed.), Complementary Methods for Research in Education (pp. 253-300). Washington DC: American Educational Research Association.

Tapia, C. E., Carmen, S. C., \& Susana, C. V. (2013). A Mexican Study of Multiple Intelligences for Pre-Service Teachers of English as a Foreign Language. HOW: A Colombian Journal for Teachers of English, 20, 170-189.

Visser, B., Ashton, M., \& Vernoon, O. (2006). Beyond g: Putting Multiple Intelligences Theory to the Test. Intelligence, 34, 487-502. http://dx.doi.org/10.1016/j.intell.2006.02.004

Wen, Q. F. (2003). The Way to Success for English Study. Shanghai: Shang Foreign Language Education Press.

Wu, W. (2009). A Study on Ambiguity Tolerance and Reading Anxiety of Non-English Majors University Students. Foreign Language Teaching and Research, 29, 98-99.

Xu, Y. (2005). Chinese Learners' Tolerance of Ambiguity in Learning English as a Foreign Language. Journal of Zhejiang Education Institute, No. 1, 24-28.

Yu, Y. (2007). The Influence of Tolerance of Ambiguity on Learning Strategies of Listening Comprehension. Unpublished MA Thesis, Jilin: Jilin University.

Zarashan, M., \& Ardeshiri, M. (2012). The Relationship between Emotional Intelligence, Language Learning Strategies and English Proficiency among Iranian EFL University Students. Journal of Educational and Instructional Studies in the World, 2, 105-114. 


\section{Submit or recommend next manuscript to SCIRP and we will provide best service for you:}

Accepting pre-submission inquiries through Email, Facebook, LinkedIn, Twitter, etc.

A wide selection of journals (inclusive of 9 subjects, more than 200 journals)

Providing 24-hour high-quality service

User-friendly online submission system

Fair and swift peer-review system

Efficient typesetting and proofreading procedure

Display of the result of downloads and visits, as well as the number of cited articles

Maximum dissemination of your research work

Submit your manuscript at: http://papersubmission.scirp.org/ 